Bangladesh J. Plant Taxon. 26(1): 29-37, 2019 (June)

(C) 2019 Bangladesh Association of Plant Taxonomists

\title{
ETHNOBOTANICAL STUDY OF MEDICINAL PLANTS IN TORUL DISTRICT, TURKEY
}

\author{
Mustafa KaraköSE*, Sefa Akbulut ${ }^{1}$ and Zafer Cemal Özkan ${ }^{1}$ \\ Giresun University, Espiye Vocational School, Program of Medicinal \\ and Aromatic Plants, Turkey
}

Keywords: Ethnobotany; Medicinal plants; Informant consensus factor.

\begin{abstract}
This study is aimed at reporting some of the plants traditionally used in the treatment of diseases by the local people living in the centre of Torul district and its surrounding villages. A face-to-face two-part questionnaire survey was conducted with 82 local people. Identification of 29 taxa belonging to 18 families has been confirmed and their medicinal uses have been recorded. In addition, the usage patterns of plant parts and purposes are recognized. Plants are mostly used in the treatment of cold and flu, stomach disorders, gynecological, cardiovascular, and respiratory diseases. The highest use value (UV) was recorded for Rosa canina (0.54) and Mentha longifolia subsp. longifolia (0.46) and the highest Informants Consensus Factor (FIC) was cited for cold and flu (0.83) followed by stomach disorders (0.75). New information for folklore medicines have been collected from the study area.
\end{abstract}

\section{Introduction}

Folk medicine refers to beliefs, attitudes and behaviours about diseases and health. It is expressed as medical practices related to the beliefs, traditions and value judgment of societies or as "home therapy" by some anthropologists (Türkdoğan, 1991). Ethnobotanical is an important science that provides research opportunities to different discipline.

Turkey is floristically rich comprising over 12,000 taxa under approximately 1251 genera and 174 families (Güner et al., 2012). It has a very rich structure compared to neighbouring and nearby regions. About $30 \%$ of the flora is endemic to Turkey and this number is higher than the total number of endemic plants of all European countries (Davis, 1965-1985; Davis et al., 1988; Güner et al., 2000).

Medicinal plants are an important part of local medical systems in the world. The ethnobotanical studies supply a valuable resource for natural drug research and development (Farnsworth, 1990). In recent years, there has been a significant increase in the use of herbal medicine. However, there are still serious shortcomings in the research data in this area (WHO, 2009). In the world, especially in rural areas, plants continue to be used in the treatment of diseases (Çakılcıoğlu and Türkoğlu, 2007; Güneş and Özhatay, 2011; Hossain and Rahman, 2018).

Date of ethnobotanical studies in Turkey is not going back many years. Researches in Turkey on ethonobotany have developed since the beginning of the Republican period in 1923 (Baytop, 1999). The Turkish people living in the countryside still continue to use plants with traditional methods as in the past (Saraç et al., 2013; Polat et al., 2015). In recent years, many studies have been carried out on medicinal and aromatic plants (Çakılcığlu et al., 2011; Akbulut, 2015; Karaköse et al., 2018). Though several ethnobotanical studies were carried out in different parts of

* Corresponding author, Email: mustafa.karakose@ giresun.edu.tr

${ }^{1}$ Karadeniz Technical University, Faculty of Forestry, Department of Forest Botany, Turkey. 
Turkey, no any ethnobotanic studies were conducted in Torul district to document the ethonomedicianl plants and their uses. The aims of the present study are to identify the ethnobotanical plants which are used traditionally by the local people of Torul district. This study identifies not only the wild plants collected for medicinal purposes by local people of Torul district in the North-East of Turkey but also uses vernacular names, part used, preparations, and traditional uses of these plants.

\section{Materials and Methods}

Torul is situated in the North-East of Turkey and on the transit road of Trabzon-Iran on the edge of Harşit stream with an area of 1049 sq. km and located between $40^{\circ} 33^{\prime 2} 26^{\prime \prime} \mathrm{N}$ and $39^{\circ} 17^{\prime} 31^{\prime \prime}$ E. Torul belongs the Colchic Sector of the Euro-Siberian Flora Region and falls within the southern part of A7 grid square according to gird system (Davis, 1965-1985).

Field surveys were carried out between 2015 and 2016. Plant materials were collected from Alınyayla, Altınpınar, Güzeloluk, Harmancık, Kirazlık, Köstere, Tokçam, Yurtköy villages and centre of Torul district. In order to identify the collected plant specimens "Flora of Turkey and the East Aegean Islands" and "List of Turkish Plants (Vascular Plants)" (Davis, 1965-1985; Davis et al., 1988; Güner et al., 2000; Güner et al., 2012) was consulted. In addition, International Plant Name Index (IPNI: http://www.ipni.org) was consulted for the author names of plant species. Endemism of plant species is determined according to Ekim et al. (2000). The voucher specimens were deposited in the Karadeniz Technical University, Faculty of Forestry Herbarium, KATO.

In the study, a two-part questionnaire was applied to total of 82 informants. Surveys were applied face to face interviews (Akbulut and Özkan, 2014). The first part of the questionnaire aimed to determine the demographic characteristics such as age, gender, education level, occupation. In the second part of the questionnaire were recorded vernacular names, part used, preparation and utilization methods, and traditional uses of the plants. A total 82 informants, 56 males and 26 females, were interviewed face to face. The average age of the participants is 55 . Some demographic characteristics of the informants are given in Table 1.

Table 1. Demographic features of the informants.

\begin{tabular}{|c|c|c|c|}
\hline Features & & Number of informants & Percentage \\
\hline \multirow[t]{2}{*}{ Gender } & Male & 56 & 68.3 \\
\hline & Female & 26 & 31.7 \\
\hline \multirow[t]{4}{*}{ Educational level } & Illiterate & 11 & 13.4 \\
\hline & Primary school & 44 & 53.7 \\
\hline & Secondary school & 21 & 25.6 \\
\hline & High school & 6 & 7.3 \\
\hline \multirow[t]{3}{*}{ Age groups } & $31-40$ & 10 & 12.2 \\
\hline & $41-50$ & 23 & 28.0 \\
\hline & $>51$ & 49 & 59.8 \\
\hline \multirow[t]{5}{*}{ Occupation } & Worker & 9 & 11.0 \\
\hline & Farmer & 29 & 35.4 \\
\hline & Artisan & 11 & 13.4 \\
\hline & Officer & 7 & 8.5 \\
\hline & Retired & 26 & 31.7 \\
\hline
\end{tabular}


To calculate the homogeneity of information obtained from different local informants, the Factor Informants Consensus (FIC) formula developed by Trotter and Logan (1986) has been used. According to this formula, FIC value ranges from 0 to 1 , where ' 1 ' indicates the highest level of informant consent -

$$
F I C=N u r-N t /(N u r-1)
$$

Where Nur denotes number of use reports from informants for a particular plant-use category, $N t$ refers the number of taxa or species that are used for that plant use category for all informants. The Use Value $(U V)$ was calculated according to the number of plants used and the number of informants (Trotter and Logan, 1986; Albuquerque et al., 2006; Abe and Ohtani, 2013) using the following formula:

$U V=U / N$

Where $U$ refers to the number of usage reports for any plant and $N$ is the number of informants.

\section{Results and Discussion}

In the present study, 29 taxa belonging to 18 families were identified from Torul district. One of the identified plants belongs to the Pteridophyta and the remaining taxa belong to the Magnoliophyta. All taxa under Magnoliophyta are in the sub-class Magnoliidae and among them herbs are represented by 18 species, shrubs by 3 species, trees by 6 species and 1 by semi-parasite (Table 2). The Rosaceae, Asteraceae and Lamiaceae are the most used families. The most preferred usage of plants is infusion (47\%), followed by raw (17\%) and decoction (15\%) (Fig. 1).

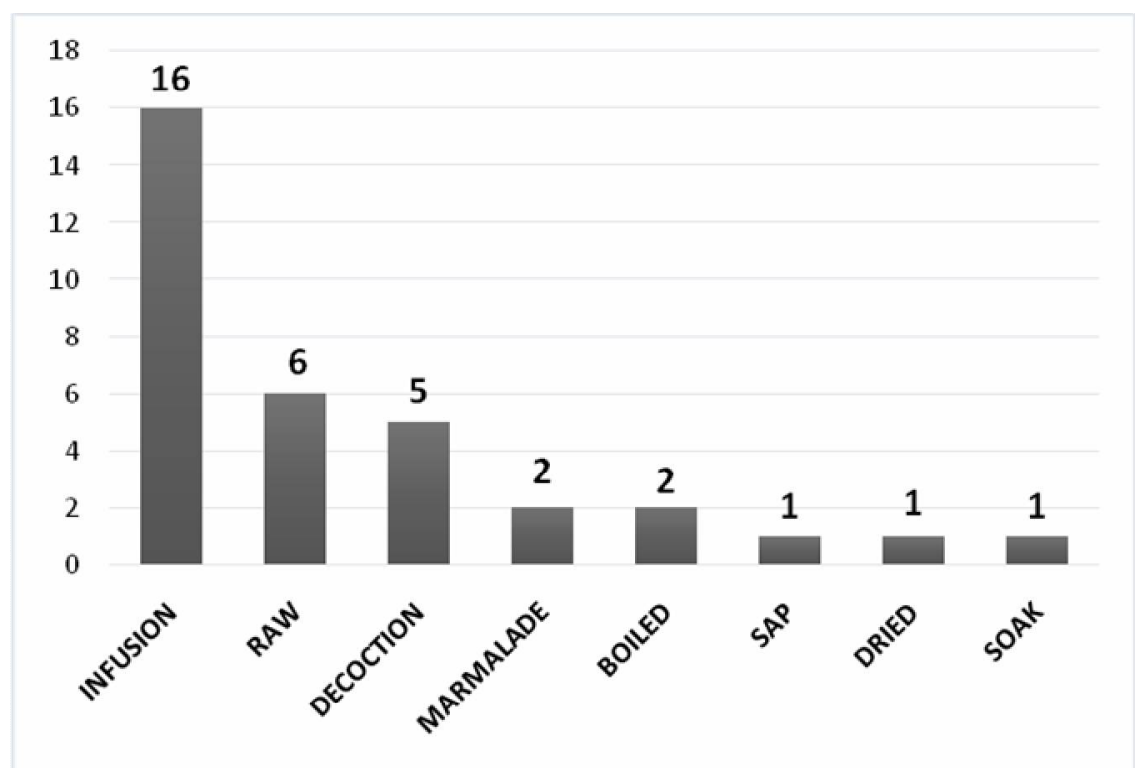

Fig. 1. Usage of plants in Torul district

The most commonly used parts of plants include leaf, fruit and flower, respectively (Fig. 2). Similar results were obtained in another study conducted in neighbouring province of Trabzon (Akbulut and Bayramoğlu, 2014). Present findings with reference to parts used were found 
consistent with some other ethnobotanical studies in the Black Sea Region (Saraç et al., 2013; Polat et al., 2015).

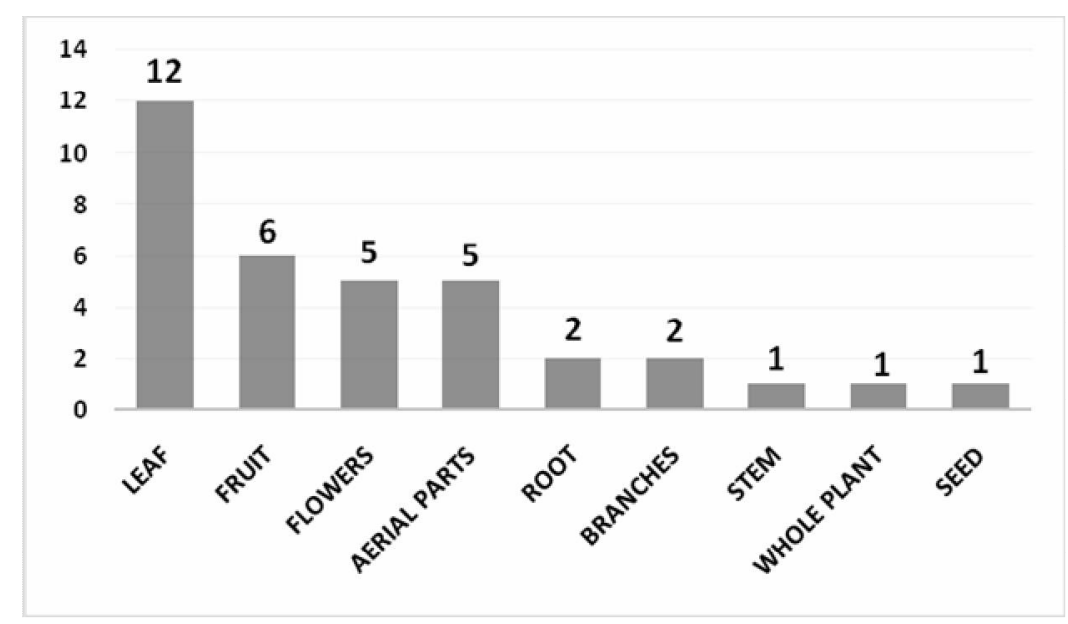

Fig. 2. The amount of usage of plant parts

The study reveals that the highest use value $(U V)$ is found in Rosa canina ( 0.54$)$ followed by Mentha longifolia subsp. longifolia (0.46), Juglans regia (0.40), Tilia rubra subsp. caucasica (0.37), Crataegus tanacetifolia (0.34), and Morus alba (0.33, Table 2).

The present study documents the use of Achillea millefolium subsp. millefolium for gynecological diseases, which was not found in previous studies (Polat et al., 2015; Çakılcığlu and Türkoğlu, 2007; Çakılcığlu and Türkoğlu, 2010). Carduus onopordioides subsp. turcicus is used for hemorrhoids which was found consistent with earlier studies (Hayta et al., 2014; Tetik et al., 2013). Due to the toxicity of Berberis crataegina, it is mixed with auxiliary substances such as honey and melted butter in the treatment of jaundice and stomach diseases.

Informant consensus factor (FIC) ranges from 0 to 1 (Table 3). The FIC values in the study range from 0.33 to 0.83 . Cold and flu has the highest FIC value 0.83 with 24 use-reports for 5 plant species. The species accountable for the high consensus (0.54) was Rosa canina out of the 82 reported cases. The taxa reported for cold and flu are Tilia rubra subsp. caucasica and Thymus longicaulis subsp. longicaulis. These are followed by stomach disorders (0.75), gynecological diseases (0.67), and skin disorders (0.64). The high FIC value for cold and flu maybe showed that this ailment is common in Torul due to cold and hard winter months especially December and January in the region. The lowest FIC values are for cardiovascular diseases (0.44) and painkiller (0.33).

There is no other study in the Torul district where the FIC value was calculated. The categories cited in the present study and their FIC values are not similar to other studies where researchers have found different FIC values. For examples, Polat et al. (2015) found the highest FIC in dermatological disorders (0.62), followed by gastrointestinal disorders (0.56) and respiratory tract problem (0.49). In a study Hayta et al. (2014) found that the FIC values range between 0.60 and 0.24 and the category skin diseases have the highest FIC, followed by throat diseases and diabetes. In a study from west of Turkey, Gürdal and Kültür (2013) showed rheumatism has the highest FIC (0.72), while skin disease has the lowest FIC (0.27). In the present study, it was found that the FIC values range between 0.33 and 0.83 . This value is one of 


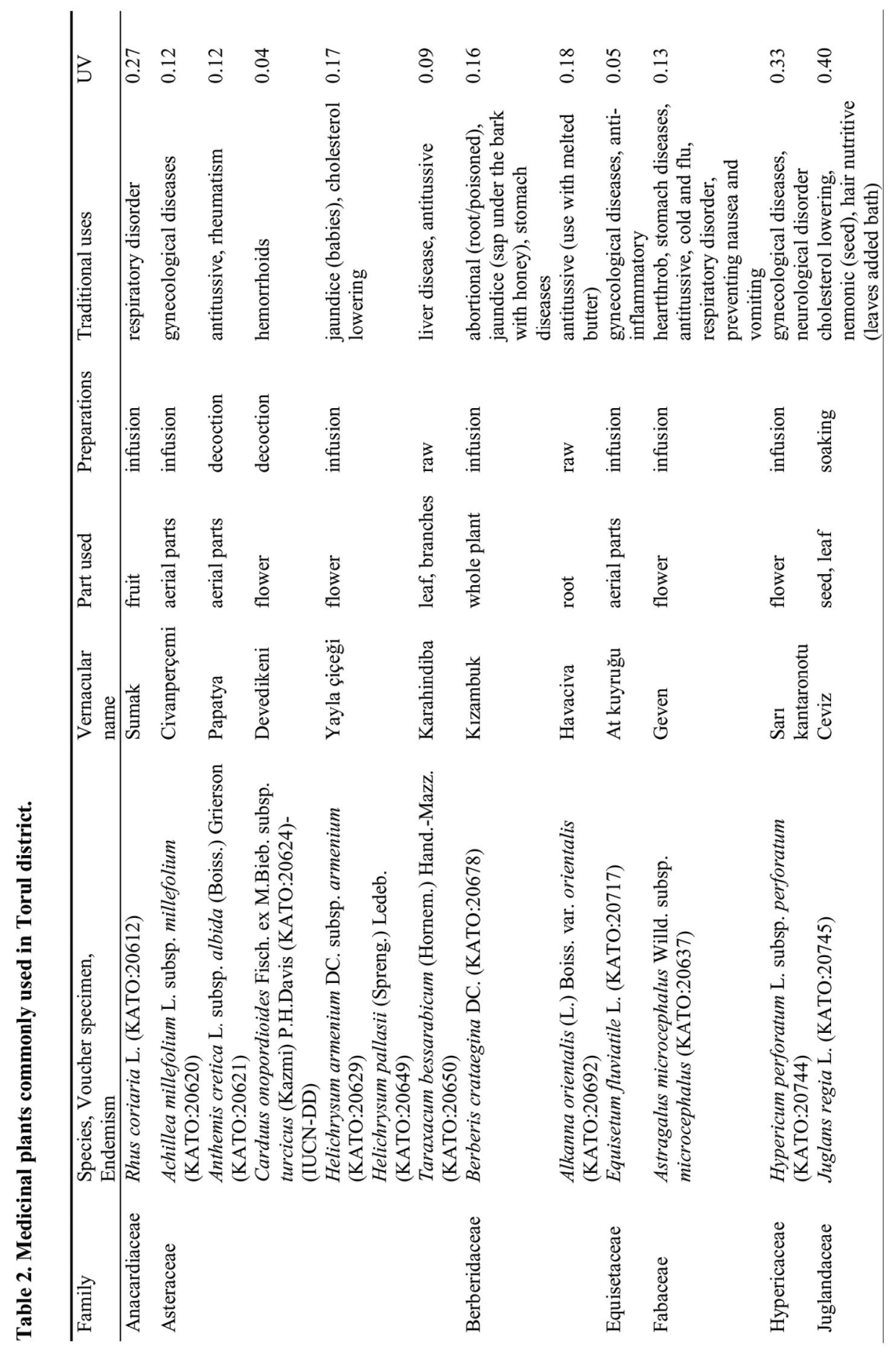




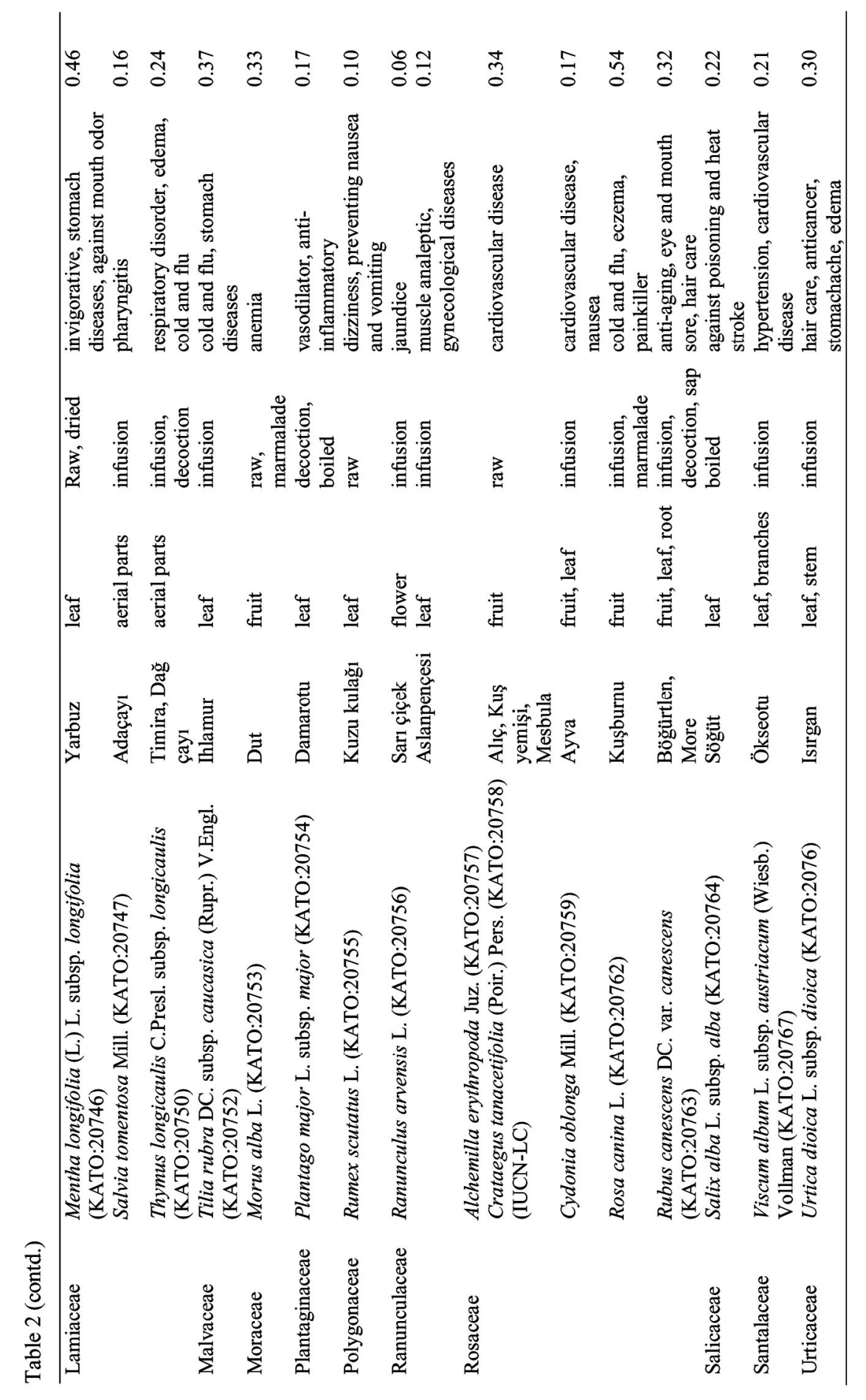


the highest FIC values in Turkey (Çakılcığlu et al., 2011; Polat et al., 2015). However, it is lower than the highest FIC values obtained in the studies conducted in various from the Turkey are 0.87 and 0.93 for Edremit gulf and Hatay region, respectively (Güzel et al., 2015; Polat and Sat1l, 2012). A similar scenario was observed in the data obtained from the studies conducted on the Iberian Peninsula: 0.85 and 0.91 for a Portuguese and a Catalan region, respectively (Bonet and Valles, 2003; Camejo-Rodrigues et al., 2003).

Table 3. Factor Informant Consensus (FIC) for each ailment.

\begin{tabular}{lccc}
\hline Ailment categories & $\begin{array}{c}\text { Number of use report } \\
(\text { Nur })\end{array}$ & $\begin{array}{c}\text { Number of taxa } \\
(N t)\end{array}$ & FIC \\
\hline Cold and flu & 24 & 5 & 0.83 \\
Stomach disorders & 17 & 5 & 0.75 \\
Gynecological diseases & 10 & 4 & 0.67 \\
Skin disorders & 12 & 5 & 0.64 \\
Respiratory diseases & 19 & 9 & 0.56 \\
Diuretic & 3 & 2 & 0.50 \\
Jaundice & 5 & 3 & 0.50 \\
Cardiovascular diseases & 10 & 6 & 0.44 \\
Painkiller & 4 & 3 & 0.33 \\
\hline
\end{tabular}

In this study, data obtained from 82 informants and 29 plant taxa belonging to 18 families used in traditional treatment were evaluated. One of the most preferred species is Rosa canina, which is used against colds. This species is quite common and is one of the most appreciated species in the food factories in the region. Juglans regia is evaluated in the making of the sugar, called "Köme", in addition to its medicinal properties. Two endemic plants used by the local people for medical purposes have been identified in the study area. Although Crataegus tanacetifolia and Carduus onopordioides subsp. turcicus are medically important endemic plants, but these characteristics are not known to local people. Studies on protection/reuse of these species and their sustainability should be carried out in these regions to ensure that these species never face the threat of extinction. In addition to their medicinal properties, some species that are also important as food and grow naturally have not yet been cultured in the region. Some species that have potential to provide significant income to the locality are Morus alba, Rhus coriaria, Rubus canescens, and Tilia rubra subsp. caucasica. Though the data obtained from this ethnobotanical study is not medical prescriptions, however, these data are the subject of research in the fields of medicine, pharmacy and chemistry for potential drug discovery.

\section{Acknowledgment}

The authors thank the Torul people and informants for their contributions to the study.

\section{References}

Abe, R. and Ohtani, K. 2013. An ethnobotanical study of medicinal plants and traditional therapies on Batan Island, the Philippines. J. Ethnopharmacol. 145: 554-565.

Akbulut, S. 2015. Differences in the traditional use of wild plants between rural and urban areas: the sample of Adana. Stud. Ethno-Med. .9(2): 141-150. 
Akbulut, S. and Bayramoğlu, M.M. 2014. Reflections of socio-economic and demographic structure of urban and rural on the use of medicinal and aromatic plants: the sample of Trabzon province. Stud. EthnoMed. 8(1): 89-100.

Akbulut, S. and Özkan, Z.C. 2014. Traditional usage of some wild plants in Trabzon region (Turkey). Kast. Uni. J. Forest. Fac. 14(1): 135-14.

Albuquerque, U.P., Lucena, R.F.P., Montero, J.M., Florentino, A.T.N. and Almeida, C.F. 2006. Evaluating two quantitative ethnobotanical techniques. Ethnobot. Res. App. 4: 51-60.

Baytop, T. 1999. Therapy with Medicinal Plants in Turkey (Past and Present), $2^{\text {nd }}$ ed. Nobel Medicine Publication, Istanbul, Turkey.

Bonet, M.A. and Valles, J. 2003. Pharmaceutical ethnobotany in the Montseny biosphere reserve (Catalonia, Iberian Peninsula). General results and new or rarely reported medicinal plants. J. Pharm. Pharmacol. 55: $259-270$.

Camejo-Rodrigues, J., Ascensao, L., Bonet, M.A. andValles, J. 2003. Anethnobotanical study of medicinal and aromatic plants in the Natural Parkof "Serra de Sao Mamede" (Portugal). J. Ethnopharmacol. 89:199-209.

Çakılcığlu, U., Khatun, S., Türkoğlu, I. andHayta, S. 2011. Ethnopharmacological survey of medicinal plants in Maden (Elazığ-Turkey). J. Ethnopharmacol.137: 469-486.

Çakılcıoğlu, U. and Türkoğlu, I. 2007. Plants used for hemorrhoid treatment in Elazığ central district. ActaHortic. 826: 89-96.

Çakılcıoğlu, U. and Türkoğlu, I. 2010. An ethnobotanical survey of medicinal plants in Sivrice (ElazıgTurkey). J. Ethnopharmacol. 132: 165-175.

Davis, P.H. (Ed.) 1965-1985. Flora of Turkey and the East Aegean Islands. Vols. 1-9. Edinburgh University Press, Edinburgh, UK.

Davis, P.H., Mill, R.R. and Tan, K. (Eds) 1988. Flora of Turkey and the East Aegean Islands. Vol. 10. Edinburgh University Press, Edinburgh, UK.

Ekim, T., Koyuncu, M., Vural, M., Duman, H., Aytaç, Z. and Adıgüzel, N. (Eds) 2000. Red Data Book of Turkish Plants (Pteridophyta and Spermatophyta). Turkish Association for the Conservation of Nature, Van Yüzüncüyıl University Press, Ankara, Turkey.

Farnsworth, N. R. 1990. The role of ethnopharmacology in drug development. In: Chadwick, D.J. and Marsh, J. (Eds.) Bioactive Compounds from Plants. CIBA Foundation Symposium 154. Wiley, Bangkok, pp. 2-11.

Güner, A., Özhatay, N. and Başer, K.H.C. (Eds.) 2000. Flora of Turkey and the East Aegean islands. Vol. 11, Supplement-II. Edinburgh University Press, Edinburgh, UK.

Güner, A., Aslan, S., Ekim, T., Vural, M. andBabaç, M.T. (Eds.) 2012. Türkiye Bitkileri Listesi (Damarl1 Bitkiler). Nezahat Gökyiğit Botanik Bahçesive Flora Araştırmaları Derneği Yayını, İstanbul, Turkey.

Güneş, F. and Özhatay, N. 2011. An ethnobotanical study from Kars (Eastern) Turkey. Bio. Di. Con. 4(1): $30-41$.

Gürdal, B. and Kültür, Ş. 2013. An ethnobotanical study of medicinal plants in Marmaris (Mugla, Turkey). J. Ethnopharmacol. 146: 113-126.

Güzel, Y., Güzelşemme, M. and Miski, M. 2015. Ethnobotany of medicinal plants used in Antakya: A multicultural district in Hatay Province of Turkey. J. Ethnopharmacol. 174: 118-152.

Hayta, S., Polat, R. andSelvi, S. 2014. Traditional uses of medicinal plants in Elazığ (Turkey). J. Ethnopharmacol. 154: 613-623.

Hossain, U. and Rahman, M.O. 2018. Ethnobotanical uses and informant consensus factor of medicinal plants in Barisal district, Bangladesh. Bangladesh J. Plant Taxon. 25(2): 241-255.

Karaköse, M., Polat, R., Rahman, M.O. and Çakılcıoğlu, U. 2018. Traditional honey production and bee flora of Espiye, Turkey. Bangladesh J. Plant Taxon. 25(1): 79-91. 
Polat, R., Çakılcıoğlu, U., Kaltalığlu, K., Ulusan, M.D. and Türkmen, Z. 2015. An ethnobotanical study on medicinal plants in Espiye and its surrounding (Giresun-Turkey). J. Ethnopharmacol. 163: 1-11.

Polat, R. and Satıl, F. 2012. An ethnobotanical survey of medicinal plants in Edremit Gulf (Balıkesir Turkey). J. Ethnopharmacol. 139: 626-641.

Saraç, D.U., Özkan, Z.C. and Akbulut, S. 2013. Ethnobotanic features of Rize/Turkey province. Bio. Di. Con, 6(3): 57-66.

Tetik, F., Civelek, S. and Çakılcığlu, U. 2013. Traditional uses of some medicinal plants in Malatya (Turkey). J. Ethnopharmacol. 146: 331-346.

Trotter, R.T. and Logan, M.H. 1986. Informant census: A new approach for identifying potentially effective medicinal plants. In: Etkin, L.N. (Ed.), Plants in indigenous medicine and diet. Routledge, Bedford Hill, NY, pp. 91-112.

Türkdoğan, O. 1991. Culture and health-disease system. Ministry of National Education Publications, İstanbul, Turkey.

WHO 2009. World Health Organization (WHO) monographs on selected medicinal plants. Vol. 4. Spain.

(Manuscript received on 10 May, 2018; revised on 16 April, 2019) 